\title{
Retailer choice and loyalty schemes—evidence from Sweden
}

\author{
Johan Lundberg • Sofia Lundberg
}

Received: 12 February 2010 / Accepted: 5 September 2010 / Published online: 17 September 2010 (C) Springer-Verlag 2010

\begin{abstract}
From economic theory, it is known that consumer loyalty schemes can have lock-in effects resulting in entry barriers and higher prices. This paper concerns consumer loyalty schemes where the main issue is to test the hypothesis that loyalty scheme membership affects the choice of food retailer. This choice is modeled as a random utility maximization problem estimated with maximum likelihood. Based on a data set covering 1551 Swedish households, we find evidence supporting this hypothesis. Further, according to the results, store characteristics and geographical distance matter for the choice of retailer while household characteristics are not found to have a significant effect.
\end{abstract}

Keywords Bonus card · Conditional logit · Consumer choice · Distance $\cdot$ Food retailer $\cdot$ Loyalty scheme

JEL Classification D12 $\cdot$ L49 $\cdot$ L66 $\cdot$ L81 $\cdot$ R10

Financial support from the Swedish Research Council for Environment, Agricultural Sciences and Spatial Planning, FORMAS, is grateful acknowledged as is insightful comments from Thomas Aronsson, Sven-Olof Daunfeldt, Henk Folmer, Lars Westin, and seminar participants at the Department of Economics at Umeå University, Centre for Regional Science, CERUM at Umeå University, Department of Economics at University of Gävle, The Swedish Research Institute of Trade (HUI), the European Association for Research in Industrial Economics Congress in Amsterdam, and two anonymous referees.

J. Lundberg · S. Lundberg $(\bowtie)$

Department of Economics, Umeå University, 90187 Umeå, Sweden

e-mail: sofia.lundberg@econ.umu.se

J. Lundberg

e-mail: johan.lundberg@econ.umu.se 


\section{Introduction}

During the last decade, consumer loyalty schemes have become increasingly common. Consumers earn points when they purchase retail trade commodities, food, gas, movie visits, flights and so forth. The design of these schemes may vary, but from the retailers' perspective the main purpose is usually to make consumers loyal. On the other hand, it could be argued that consumers benefit from loyalty schemes because they 'feel selected', earn 'points' or receive rebates. However, these schemes can also impose an artificial switching cost on the consumers. Theoretically, switching costs ${ }^{1}$ can lead to welfare losses for the society (Klemperer 1987, 1995; Beggs and Klemperer 1992), deter market entry, (e.g. Cairns and Galbraith 1990), and make consumer buy brands other than those they actually prefer (Gans and King 2006). Empirical studies of frequent flyer schemes show that they affect the behavior of the consumers and the pricing of flight tickets. ${ }^{2}$

In this paper we use Swedish data from 2004 to empirically test the hypothesis that a representative household is more likely to choose a food retailer if it is a member of a loyalty scheme associated with that retailer. ${ }^{3}$ The spatial dimension and other potentially important determinants are also accounted for.

Analyses of the effects of loyalty schemes in Sweden are motivated by the fact that 92.5 percent of all food stores in Sweden are connected to one or other of three food retailer chains (Nordic Competition Authorities 2005). The market could be described as an oligopoly where the effects of loyalty schemes might exacerbate already existing market imperfections. In addition, food expenditures, in general, constitute a large share of a household's total expenditures. ${ }^{4}$

However, empirical studies of the effects of loyalty schemes on the special features of the food market are scarce. Results from the well-covered marketing literature (e.g. Uncles 1994; Sharp and Sharp 1997; Lal and Bell 2003; Mauri 2003) show that loyalty schemes are of value to the supply side as they establish long term customer relationships, increase revenues, and generate valuable information about customers' shopping behavior (e.g. Ziliani and Bellini 2004; Pauler and Dick 2006). Loyalty, in terms of the share of visits to a specific store, and profits are found to be positively correlated (e.g. Mägi and Julander 1996; Smith et al. 2003). ${ }^{5}$

Empirical studies in the economics literature on consumer loyalty where loyalty is not related to loyalty schemes, find that consumers tend to be loyal in general (e.g. Fox et al. 2004; Knox and Denison 2000; Bell and Lattin 1998). However, none

\footnotetext{
${ }^{1}$ Nilssen (1992) defines two types of switching costs; a transaction cost that arises at every switch and a learning cost that is incurred by the consumer who switches to a previously unknown store.

${ }^{2}$ See for example Nako (1992), Proussaloglou and Koppelman (1999), Storm (1999), the Swedish Competition Authority (2003), Carlsson and Löfgren (2004).

${ }^{3}$ Loyalty schemes associated with every day commodities (food included) began to be introduced in Europe during the 1990s (see Sharp and Sharp 1997; Mauri 2003) and the first appeared in Sweden in 1989.

${ }^{4}$ According to Statistics Sweden (SCB), figures from 2004 show that food and non-alcoholic beverages comprises 14.6 percent of Swedish households' total expenditures.

${ }^{5}$ The Mägi and Julander (1996) study is based on 220 in-store distributed questionnaires from four stores in Sweden associated with the same retailer and the findings rest on Spearman's rank correlation coefficients and comparisons of means while the Smith et al. study (2003) is a diary study based on 30 informants.
} 
of these studies explicitly include information on the households' possession of club cards and as such our paper complements Mauri (2003), Lal and Bell (2003), Cortiñas et al. (2008). In addition, this paper contributes to the previous literature (e.g. Khan and Schmittlein 1989; Fox et al. 2004) by including information in the analysis on the household's complete choice set.

The rest of this paper is organized as follows. The data and the variables included in the empirical analysis are presented in Sect. 2. In Sect. 3 the theoretical approach and the empirical specification is outlined. The results and their robustness are discussed in Sect. 4 and Sect. 5 concludes the paper.

\section{Data}

Household characteristics have been collected by means of a questionnaire sent to a representative sample with respect to age of 3000 households in the six municipalities that form the Umeå region in Northern Sweden. The sample was stratified with respect to age and location. The mail survey was carried out in October 2004 and one person within each household was asked to answer the questionnaire on behalf of the household as a whole. The response rate was 53-percent. The share of questionnaires sent to each of the six municipalities was weighted with the population. As can be seen in Table 1, the data is fairly representative in terms of the preserved weights attached to each municipality.

The data include household characteristics and its food shopping behavior with respect to choice of primary store for large basket shopping. The household was asked to list one store where it primarily does its large basket shopping and the monthly amount spent in the store. In total the respondents listed 117 food stores in the Umeå region. These are basically all the food stores of significant size in the region. Descriptive statistics on store and household characteristics are displayed in Table 2. Information on store service level was collected on site in each and every store. The service indicators included here form a dummy variable that takes the value one if the store entrance and cash-point are accessible for disabled persons and another dummy variable that takes the value one if the store has a certificate to show that it follows good environmental practices. Further, a service index $\left(S I_{j}\right)$ reflecting whether the store has a meat, a cheese, and/or a fish delicatessen counter is included, where

Table 1 Population in the Umeå region and response rate

\begin{tabular}{lccc}
\hline Municipality & Population in 2004 & Share of questionnaires & Share of response rate \\
\hline Bjurholm & 2588 & 1.8 & 1.7 \\
Nordmaling & 7511 & 5.4 & 5.4 \\
Robertsfors & 7106 & 5.0 & 4.5 \\
Umeå & 109390 & 77.3 & 78.2 \\
Vindeln & 5773 & 4.2 & 4.0 \\
Vännäs & 8525 & 6.1 & 6.1 \\
Total & 140893 & 100 & 100 \\
\hline
\end{tabular}


Table 2 Number of stores within each retailer category that can offer a specific service (percent in parenthesis) and descriptive statistics for opening hours, assortment, and household characteristics

\begin{tabular}{|c|c|c|c|c|}
\hline & \multicolumn{4}{|c|}{ Retailer category } \\
\hline & $\mathrm{ICA}$ & Konsum/COOP & Other & All \\
\hline Meat deli & $18(44)$ & $14(70)$ & $1(2)$ & $33(28)$ \\
\hline Cheese deli & $16(39)$ & $8(40)$ & $1(2)$ & $25(21)$ \\
\hline Fish deli & $6(15)$ & $10(50)$ & $0(-)$ & $16(14)$ \\
\hline $\begin{array}{l}\text { Accessible for } \\
\text { disabled persons }\end{array}$ & $33(80)$ & $19(95)$ & $37(66)$ & $89(76)$ \\
\hline Price info. station & $16(39)$ & $15(75)$ & $2(4)$ & $33(28)$ \\
\hline Environment certificate & $6(15)$ & $8(40)$ & $2(4)$ & $16(14)$ \\
\hline$S I_{j}=3$ & $6(15)$ & $4(20)$ & $0(-)$ & $10(8)$ \\
\hline$S I_{j}=2$ & $10(24)$ & $4(20)$ & $1(2)$ & $15(13)$ \\
\hline$S I_{j}=1$ & $2(5)$ & $6(30)$ & $0(-)$ & $8(7)$ \\
\hline Total & $41(100)$ & $20(100)$ & $56(100)$ & $117(100)$ \\
\hline \multicolumn{5}{|l|}{ Opening hour weekdays } \\
\hline Min/Max & $8 / 24$ & $8 / 12$ & $7 / 24$ & $7 / 24$ \\
\hline Mean & 10.8 & 10.6 & 13.3 & 11.9 \\
\hline Std. dev. & 2.7 & 1.2 & 3.6 & 3.2 \\
\hline \multicolumn{5}{|l|}{ Opening hour Saturday } \\
\hline Min/Max & $3 / 24$ & $3 / 12$ & $0 / 24$ & $0 / 24$ \\
\hline Mean & 8.4 & 8.3 & 11.9 & 10.1 \\
\hline Std. dev. & 3.8 & 3.1 & 4.4 & 4.3 \\
\hline \multicolumn{5}{|l|}{ Opening hour Sunday } \\
\hline Min/Max & $0 / 24$ & $0 / 12$ & $0 / 24$ & $0 / 24$ \\
\hline Mean & 6.1 & 6.3 & 10.5 & 8.2 \\
\hline Std. dev. & 5.2 & 4.6 & 5.7 & 5.7 \\
\hline \multicolumn{5}{|l|}{ Assortment } \\
\hline Min/Max & $62.6 / 96.5$ & $77.2 / 97.1$ & $1.2 / 97.1$ & $1.2 / 97.1$ \\
\hline Mean & 85.4 & 90.8 & 35.2 & 62.3 \\
\hline Std. dev. & 7.6 & 5.3 & 23.26 & 31.1 \\
\hline$N$ & 41 & 20 & 56 & 117 \\
\hline \multicolumn{5}{|c|}{ Descriptive statistics households } \\
\hline & Mean & Std. dev. & Min/Max & $N$ \\
\hline Family size, no. of persons & 2.4 & 1.3 & $1 / 11$ & 1553 \\
\hline $\begin{array}{l}\text { Household } \\
\text { monthly income } \\
\text { (SEK) }\end{array}$ & 28625.2 & 17404.7 & $0 / 75000$ & 1553 \\
\hline Number of cars & 1.2 & 0.8 & $0 / 7$ & 1553 \\
\hline \multicolumn{5}{|c|}{ Distance in kilometers between the home and the store } \\
\hline Home—selected store & 6.3 & 10.0 & $0.2 / 93.7$ & 1551 \\
\hline Home-alternative store & 9.8 & 13.2 & $0.1 / 98.9$ & 3102 \\
\hline
\end{tabular}


$S I_{j} \in[0,3]$. Opening hours are included to reflect household preferences for timewise accessibility. Here, three continuous variables are used, one for the number of opening hours weekdays, Saturdays, and Sundays, respectively. On average stores are open 12 hours on weekdays, 10 hours on Saturdays, and 8 hours on Sundays.

The Swedish Consumer Agency has defined a food basked that is primarily used for measuring price levels and it includes 171 items. In the empirical model, assortment is defined as the share of items on the list that was stocked by each store. This data was collected on site at each store.

Households are heterogeneous in taste. According to e.g. Blattberg et al. (1978) and Hoch et al. (1995), differences in taste may also reflect differences in alternative costs for time. It is assumed that households with children, retired people, students, and people working part time have different preferences than those in full time employment. As in e.g. McGoldrick and Andre (1997) and Fox et al. (2004), the household composition is also accounted for by family size and education level. The latter is a dummy variable that takes the value one if at least one person within the household has higher education.

The number of cars that the household has in its possession is included in order to control for differences in accessibility to distant stores and flexibility with regards to the means of transportation between households. The effect of income is also considered and is measured as the total monthly gross household income in Swedish kronor (SEK). The income variable is originally measured in intervals, which is transformed into a continuous variable by taking the middle value in each interval. ${ }^{6}$ Consideration is also given to the household's opportunities to store food by a dummy variable that takes the value one if the household has an additional freezer.

The distance to a store within each retailer category is likely to be one important factor for the choice of store. Inherent in the distance measure is, given the road network in the region, the travel time. As in Bell and Lattin (1998), the distance measure is based on the household's and the store's 5 digit postal code. Instead of measuring the distance from the centroids of each postal code area the postal codes are linked to their geographical coordinates and then the distance is calculated as the Euclidian distance in ten kilometers. The effect of distance is assumed to be decreasing and therefore enters the model in a non linear form. The use of the home address as the departure point is motivated by the fact that a majority (about 75 percent) of the households reported that they never, seldom, or only occasionally shop food when commuting to or from work.

The variable vector $(z)$ that will be used to establish whether loyalty scheme membership is important for the choice of retailer is defined as three dummy variables, one for each retailer category: ICA, Konsum/COOP, and Other (reference category). It takes the value one if the household has a club card associated with retailer $j$, otherwise zero. As shown in Table 3 a vast majority are members of at least three loyalty schemes, e.g. 87.5 percent of the Konsum/COOP members are also members of the ICA loyalty scheme. The effect of loyalty program membership on store choice is assumed to be exogenous. This is motivated by the time lag between the introduction

\footnotetext{
${ }^{6}$ Questions about earnings are in general considered as a delicate question and one way to avoid missing values or lose response rate is to design the income question with multiple alternatives.
} 
Table 3 Distribution of Club or Credit cards among households

\begin{tabular}{|c|c|c|c|c|}
\hline \multirow{2}{*}{$\begin{array}{l}\text { Card name } \\
\\
\text { No cards }\end{array}$} & \multicolumn{2}{|c|}{$\begin{array}{l}\text { Nr. of households } \\
\text { (percent) }\end{array}$} & \multirow{2}{*}{$\begin{array}{l}\text { Share of } \\
\text { ICA-Kundkort } \\
\text { Card holders that } \\
\text { also have another } \\
\text { card } \\
\text { - }\end{array}$} & \multirow{2}{*}{$\begin{array}{l}\text { Share of COOP } \\
\text { MedMera Card } \\
\text { holders that also } \\
\text { have another card } \\
\\
\text { - }\end{array}$} \\
\hline & 34 & $(2.2)$ & & \\
\hline ICA-Kundkort (food) & 1234 & $(79.5)$ & - & 87.1 \\
\hline Konsum/COOP MedMera (food) & 1094 & $(70.4)$ & 77.2 & - \\
\hline Hemköp Kundkort (food) & 16 & $(1.0)$ & 1.1 & 1.5 \\
\hline Statoil (gas station) & 293 & $(18.9)$ & 21.6 & 21.9 \\
\hline OK/Q8 (gas station) & 541 & $(34.8)$ & 38.5 & 43.3 \\
\hline Preem (gas station) & 73 & $(4.7)$ & 5.6 & 6.1 \\
\hline Shell (gas station) & 118 & $(7.6)$ & 8.8 & 9.1 \\
\hline $\begin{array}{l}\text { Bank Card (Visa, } \\
\text { Master card etc.) }\end{array}$ & 1194 & $(76.9)$ & 80.5 & 81.3 \\
\hline Other & 99 & $(6.4)$ & 7.2 & 7.5 \\
\hline Total & 1553 & & & \\
\hline
\end{tabular}

of these programs and the point in time of our survey (approximately 15 years, see footnote 3 ). That is, loyalty programs have been on the market for a long time, and households have equipped themselves with multiple sets of loyalty program memberships, see Table 3. Then, conditional on their loyalty memberships, the household make their choice of retailer.

\section{Theoretical and empirical approach}

The household's choice of food retailer for its large basket shopping is modeled as a random utility maximization problem where the representative household $i$ is assumed to choose one retailer $j(j=0, \ldots, J)$ over another if the utility of that choice is higher than the utility from choosing any of the other alternative retailers. The random utility function is defined as

$$
U_{i j}\left(x_{j}, q_{i}, z_{i}\right)=x_{j}^{\prime} \beta_{x}+q_{i}^{\prime} \beta_{q}+z_{i}^{\prime} \beta_{z}+\varepsilon_{i j}
$$

where $x_{j}$ is characteristics of the retailer, $q_{i}$ is the characteristics of the household, and $z_{i}$ is a dummy variable that indicates whether household $i$ is a member of a loyalty scheme associated with retailer $j$ or not. The $\beta$ 's are parameters to be estimated and $\varepsilon_{i j}$ is the error term.

In order to test the hypothesis that a representative household is more likely to select a food retailer if it is a member of the retailer's loyalty scheme, the random utility function specified in (1) is treated as a conditional logit model and estimated with maximum likelihood (McFadden 1974; Chamberlain 1980). Each household is given three choice alternatives, $j=1, \ldots, 3$ a ICA store, a Konsum/COOP store, 
and a store from the category "other stores". Interactions of household characteristics with the choice alternatives are included to incorporate the effect of household characteristics in the empirical analysis (see Greene 2008). Interaction variables are also required for inclusion of the loyalty scheme membership $\left(z_{i}\right)$. Two outcomes are needed in order to find support in favor of the hypothesis that a household is more likely to select a retailer if it is a member of that retailer's loyalty scheme. Firstly, the coefficient for the interaction variables between retailer $j$ and membership in a loyalty scheme associated with retailer $j$ needs to be significant and to have a positive sign. Secondly, the coefficients for interaction between retailer $k \neq j$ and membership in a loyalty scheme associated with retailer $j$ should either be insignificant or, if significant, have a negative sign. The "other stores" category is the reference alternative to the interaction variables.

Assumptions have to be made about the store within each retailer category that is the most relevant choice alternative to the one selected. We test for two specifications of the choice set. In the first specification (Spec I), the relevant choice alternative within each category is assumed to be the store located nearest to the observed choice within the same or larger store format in relation to the observed choice. If the observed choice is a hypermarket the alternative store within the category "other stores" is allowed to be of the size format below since there is no hypermarket within that category. In the second specification (Spec II), the size format restriction is relaxed which means that the relevant choice alternatives are stores within the other two categories that are nearest to the observed choice irrespective of store format. ${ }^{7}$

\section{Results}

The parameter estimates and corresponding $t$-values from the maximum likelihood estimation of (1) based on Spec I and Spec II is found in the first and second column in Table 4, respectively. The results in column (1) suggest that the coefficients representing the interaction between loyalty scheme associated with retailer $j$ and retailer category $j$, are positive and significant if $j=I C A$ or $j=$ Konsum/COOP. That is, the probability that the household will choose a store associated with a specific retailer for its large basket shopping is positively affected if the household has a club card associated with that retailer if the retailer is ICA or Konsum/COOP. Further, the interaction coefficients for "Other stores" are not significant. This not surprising given that this is an aggregate of retailers. Further, the cross interaction coefficients are negative but (retailer category $j$ and club card associated with retailer $k \neq j$ ) not significant.

This result is taken as evidence in favor of the hypothesis that households are more likely to shop at a store associated with retailer $j$ if they are members of that retailer's loyalty scheme and the store is part of either of the two dominating food retailers in

\footnotetext{
${ }^{7}$ In a possible third specification, the household could be assigned a choice set that includes all 117 stores listed in the questionnaire by the households. However, due to the extensive number of interaction variables that would be needed to estimate the choice of retailer, we have chosen not to estimate a model built on $J=117$.
} 
Table 4 Estimation results, conditional logit. $J=3$

\begin{tabular}{|c|c|c|c|c|}
\hline & \multicolumn{2}{|c|}{$\begin{array}{l}\text { (1) Spec I } \\
\text { (distance and format restriction) }\end{array}$} & \multicolumn{2}{|c|}{$\begin{array}{l}\text { (2) Spec II } \\
\text { (distance restriction only) }\end{array}$} \\
\hline & Parameter estimate & $t$-value & Parameter estimate & $t$-value \\
\hline \multicolumn{5}{|l|}{ Loyalty member variables } \\
\hline ICA card interaction ICA & 3.21 & 5.08 & 3.32 & 3.74 \\
\hline ICA card interaction COOP & 0.23 & 0.37 & -0.07 & -0.08 \\
\hline COOP card interaction ICA & -0.74 & -1.17 & -1.14 & -1.24 \\
\hline COOP card interaction COOP & 2.12 & 3.45 & 2.29 & 2.44 \\
\hline Other card interaction ICA & -1.16 & -1.74 & -1.63 & -1.68 \\
\hline Other card interaction COOP & -1.12 & -1.68 & -1.44 & -1.47 \\
\hline \multicolumn{5}{|l|}{ Store characteristics } \\
\hline Distance household—store & -0.48 & -13.49 & 0.04 & 2.02 \\
\hline$(\text { Distance household-store })^{2}$ & 0.00 & 5.27 & -0.00 & -0.31 \\
\hline Assortment & 0.18 & 6.83 & 0.26 & 13.32 \\
\hline Accessibility for disabled persons & 0.29 & 1.11 & -0.67 & -2.81 \\
\hline Service index & -0.36 & -6.51 & -0.28 & -5.33 \\
\hline Opening hours weekdays & 0.52 & 4.06 & 0.19 & 2.07 \\
\hline Opening hours Saturday & 0.04 & 0.42 & -0.12 & -1.43 \\
\hline Opening hours Sunday & -0.11 & -1.79 & 0.02 & 0.33 \\
\hline Environment certificate & -0.64 & -5.06 & -0.53 & -3.66 \\
\hline Price information & 0.23 & 0.37 & 0.08 & 0.53 \\
\hline \multicolumn{5}{|l|}{ Household characteristics ICA } \\
\hline Constant & 4.01 & 5.69 & -2.42 & -2.33 \\
\hline Family size & -0.08 & -0.34 & 0.29 & 0.87 \\
\hline Number of cars & 0.38 & 0.76 & -0.26 & -0.40 \\
\hline Household income & 0.00 & 1.14 & 0.00 & 1.20 \\
\hline Higher education dummy (Yes $=1$ ) & -1.35 & -2.37 & -1.08 & -1.26 \\
\hline Part time work dummy $($ Yes $=1)$ & -0.08 & -0.13 & 0.57 & 0.58 \\
\hline Student dummy $($ Yes $=1)$ & -0.32 & -0.59 & 0.23 & 0.23 \\
\hline Extra freezer $($ Yes $=1)$ & -0.00 & -0.00 & -0.73 & -0.76 \\
\hline \multicolumn{5}{|l|}{ Household characteristics COOP } \\
\hline Constant & 3.14 & 4.34 & -4.04 & -3.82 \\
\hline Family size & -0.06 & -0.27 & 0.30 & 0.92 \\
\hline Number of cars & 0.41 & 0.83 & -0.15 & -0.82 \\
\hline Household income & 0.00 & 1.23 & 0.00 & 1.30 \\
\hline Higher education dummy (Yes = 1) & -1.24 & -2.17 & -1.04 & -1.21 \\
\hline Part time work dummy (Yes = 1) & -0.31 & -0.49 & 0.14 & 0.15 \\
\hline Student dummy $($ Yes $=1)$ & -0.88 & -1.57 & -0.14 & -0.14 \\
\hline Extra freezer $($ Yes $=1)$ & 0.27 & 0.41 & -0.58 & -0.60 \\
\hline Log likelihood value & & -674.60 & & -494.38 \\
\hline Pseudo $R^{2}$ & & 0.60 & & 0.71 \\
\hline$\chi^{2}(30)$ & & 2058.72 & & 2419.13 \\
\hline Number of observations & & 4653 & & 4653 \\
\hline
\end{tabular}


Sweden. The sign of the parameters for the geographical distance suggests that the distance effect on the likelihood of a certain store choice is negative but decreasing.

All the coefficients for the store characteristics, except for the ones reflecting whether the store is accessible for disabled persons and whether it has a price information station are significant. Assortment and the opening hours on weekdays are estimated to have a positive effect while the service index and environment certificate coefficient are estimated to have a negative effect. Notable is that the opening-hours during weekends does not have a significant impact on the probability that household $i$ will select a store associated with retailer $j$. A possible interpretation is that the time restriction is more severe during the week. The negative sign of the service index coefficient can be explained by that delicatessen counters are not what the consumers are looking for when they are doing large basket shopping.

The likelihood that a household will choose one of the three categories over another is, in principal, not explained by the household characteristics. The exceptions are the constants, which display a significant average effect of unidentified factors and a difference in preferences between a store associated with ICA or Konsum/COOP and other stores explained by the educational level in the household.

The predicted probabilities from our model almost perfectly agree with the observed probabilities suggesting that the model is fairly accurate. This is also what the pseudo $R^{2}$ values presented in Table 4 suggest.

Parameter estimates and corresponding $t$-values based Spec II are presented in the second column in Table 4. Compared with the results based on Spec I the coefficient for loyalty scheme is still positive and significant. The other estimates are also fairly robust for changes in the model specification by one exception, the distance coefficients that show the opposite signs compared to Spec I. The results based on Spec II provide no clear guidance as to which specification is the most appropriate. However, we argue in favor of the first specification (Spec I). An assignment of relevant store alternatives within the retailer categories based on store format seems reasonable.

\section{Summary}

In sum, our results suggest that households are loyal with respect to their choice of retailer for large basket shopping based on their loyalty scheme membership. Moreover, the results show that accessibility both in geographical terms and time wise (week days) matters for the probability of choice of food retailer as does the character of the store within each retailer group. Thus, it is not who the consumer is but what the retailer can offer its potential costumers that matters. Almost no significant coefficients were found for household characteristics.

\section{References}

Beggs, A., Klemperer, P.: Multi-period competition with switching costs. Econometrica 60, 651-666 (1992)

Bell, D.R., Lattin, J.M.: Shopping behavior and consumer preference for store price format: why "large basket" shoppers prefer EDLP. Mark. Sci. 17, 66-88 (1998) 
Blattberg, R.C., Buesing, T., Peacock, P., Sen, S.K.: Identifying the deal prone segment. J. Mark. Res. 15, 369-377 (1978)

Cairns, R.D., Galbraith, J.W.: Artificial compatibility, barriers to entry and frequent flyer programs. Can. J. Econ. 23, 807-816 (1990)

Carlsson, F., Löfgren, Å.: Airline choice, switching costs and frequent flyer programs. Working papers in Economics no. 123. Gothenburg University (2004)

Chamberlain, G.: Analysis of covariance with qualitative data. Rev. Econ. Stud. 47, 225-238 (1980)

Cortiñas, M., Elorz, M., Múgica, J.M.: The use of loyalty-cards databases: differences in regular price and discount sensitivity in the brand choice decision between card and non-card holders. J. Retail. Consum. Serv. 15, 52-62 (2008)

Fox, E.J., Montgomery, A.L., Lodish, L.M.: Consumer shopping and spending across retail formats. J. Bus. 77, 25-60 (2004)

Gans, J.S., King, S.P.: Paying for loyalty: product bundling in oligopoly. J. Indust. Econ. 54, 43-62 (2006)

Greene, W.H.: Econometric Analysis, 6 edn. Prentice-Hall, New York (2008)

Hoch, S.J., Kim, B.-D., Montgomery, A.L., Rossi, P.E.: Determinants of store-level price elasticity. J. Mark. Res. 39, 41-57 (1995)

Khan, B.E., Schmittlein, D.C.: Shopping trip behavior: an empirical investigation. Mark. Lett. 1, 55-70 (1989)

Klemperer, P.: Markets with switching costs. Q. J. Econ. 102, 375-394 (1987)

Klemperer, P.: Competition when consumers have switching costs: an overview with applications to industrial organization, macroeconomics and international trade. Rev. Econ. Stud. 62, 515-539 (1995)

Knox, S.D., Denison, T.J.: Store loyalty: its impact on retail revenue. An empirical study of purchasing behaviour in the UK. J. Retail. Consum. Serv. 7, 33-45 (2000)

Lal, R., Bell, D.E.: The impact of frequent shopper programs in grocery retailing. Quantit. Mark. Econ. 1, 179-202 (2003)

Mauri, C.: Card Loyalty. A new emerging issue in grocery retailing. J. Retail. Consum. Serv. 10, 13-25 (2003)

McFadden, D.L.: Conditional logit analysis of qualitative choice behavior. In: Zarembka, P. (ed.) Frontier in Econometrics, pp. 105-142. Academic Press, San Diego (1974)

McGoldrick, P.J., Andre, E.: Consumer misbehaviour, promiscuity or loyalty in grocery shopping. J. Retail. Consum. Serv. 4, 73-81 (1997)

Mägi, A., Julander, C.-R.: Perceived service quality and customer satisfaction in a store performance framework. J. Retail. Consum. Serv. 3, 33-41 (1996)

Nako, S.M.: Frequent flyer programs and business travelers: an empirical investigation. Logist. Transp. Rev. 28, 395-414 (1992)

Nilssen, T.: Two kinds of consumer switching costs. Rand J. Econ. 23, 579-589 (1992)

Nordic Competition Authorities: Nordic food markets-a taste for competition. November 2005. Report No. 1/2005 (2005)

Pauler, G., Dick, A.: Maximizing profit of food retailing chain by targeting and promoting valuable customers using loyalty card and scanner data. Eur. J. Oper. Res. 174, 1260-1280 (2006)

Proussaloglou, K., Koppelman, F.S.: The choice of air carrier, flight, and fare class. J. Transp. Manag. 5, 193-201 (1999)

Sharp, B., Sharp, A.: Loyalty schemes and their impact on repeat-purchase loyalty patterns. Int. J. Res. Mark. 14, 473-486 (1997)

Smith, A., Sparks, L., Hart, S., Tzokas, N.: Retail loyalty schemes: results from a consumer diary study. J. Retail. Consum. Serv. 10, 109-119 (2003)

Statistics Sweden (SCB). www.scb.se

Storm, S.: Air transport policies and frequent flyer programmes in the European community—a Scandinavian perspective. Report, Unit of Tourism Research at Research Centre of Bornholm, May 1999

Swedish Competition Authority: Smakar det så kostar det - En utredning med fokus på flygbonusprogram. Konkurrensverk. Rapp.ser. 2003:1 (2003)

Uncles, M.: Do you or your customers need a loyalty scheme. J. Target. Meas. Anal. 2, 335-350 (1994)

Ziliani, C., Bellini, S.: Retail micro-marketing strategies and competition. Int. Rev. Retail Distrib. Consum. Res. 14, 7-18 (2004) 